\title{
Computational Method for Supporting Learning with Cumulative Vocabularies, Conceptual Networks and Wikipedia Linkage
}

\author{
Lauri Lahti \\ Department of Computer Science and Engineering \\ Aalto University School of Science, Finland
}

\begin{abstract}
In this research paper we propose a new educational framework based on guided exploration in scale-free small-world networks relying on hyperlink network of the Wikipedia online encyclopedia in which hyperlinks between articles define conceptual relationships. Educational material is presented to student with cumulative conceptual networks based on hyperlink network of the Wikipedia connecting concepts of vocabulary about current learning topic. Personalization of educational material is carried out by alternating the distribution of enabled hyperlinks connecting concepts belonging to current vocabulary according to requirements of learning objective, learning context and learner's knowledge. Besides developing a computational method to manage educational material with conceptual networks and to explore the shortest paths between concepts of vocabulary (especially highest-ranking hyperlinked concepts and strongly rising hyperlinked concepts), we have also experimentally estimated properties of conceptual networks generated based on hyperlink network of the Wikipedia between concepts retrieved from English Vocabulary Profile for cumulatively vocabularies of six language ability levels and from Oxford Wordlist for partially cumulative vocabularies of five school levels.
\end{abstract}

\section{Introduction}

Previous research has shown that scale-free small-world networks offer efficient compact link structures that seem to exist in many natural processes. Using scale-free small-world networks can help to minimize paths required to form connectivity between nodes of the network and to maintain this property also when the network grows or experiences other modifications. Previous research has identified in human brain networks emergence of small-world topology [1] and possibly scale-free properties [38]. Thus we think that representation of knowledge in form of scale-free small-world networks should be encouraged to support various knowledge management tasks and especially learning. Currently one of the biggest freely accessible knowledge resources is collaboratively built Wikipedia online encyclopedia that has been shown to naturally represent a smallworld topology [2] and scale-free properties [39]. Motivated by previous research we now propose a new framework to support learning based on knowledge structures inspired by the hyperlink network of the Wikipedia and we supply this proposal with some promising experimental results relying on our empirical analysis of properties of conceptual networks that we have generated based on the Wikipedia.

\section{Previous work}

It has been estimated that a human vocabulary is about 4000-5000 word families for a native 5-yearold child and grows by about 1000 word families every year to reach about vocabulary of 20000 word families for a native university graduate [3]. There are possibly well over 54000 word families in English [3] but a non-native highly educated adult can manage sufficiently already with 8000-9000 word families [4]. Understanding 95 percent of general texts has been considered sufficient for reasonable comprehension [5] corresponding to a vocabulary of $3000-5000$ or just 2000-3000 word families [3].

Common European Framework of Reference for Languages (CEFRL) offers guidelines about how to measure language ability with six progressive levels that have been supplied with illustrative descriptors created and scaled with Rash modelling based on Swiss surveys in 1994-1995 covering 300 teachers and 2800 learners [6] [7]. These six levels of language ability in increasing order of expertise have been labeled with names A1 (Breakthrough), A2 (Waystage), B1 (Threshold), B2 (Vantage), C1 (Effective operational proficiency) and $\mathrm{C} 2$ (Mastery). Estimates about how many guided hours of learning are required to reach the language ability levels A2-C2 of CEFRL include 180-200 hours for A2, 350-400 hours for B1, 500-600 hours for B2, 700-800 hours for $\mathrm{C} 1$ and 1000-1200 hours for $\mathrm{C} 2$ [8] [9]. On the other hand, time required to adopt professional proficiency in a foreign language by a native English speaker has been estimated to range from 23-24 weeks or 575-600 class hours (language closely related to English, for example French) to 88 weeks or 2200 class hours (language which is exceptionally difficult, for example Arabic) [10]. 
It is possible to estimate at least coarsely the amount of information processing in learning by using measures that have been indentified for wordbased information input and output for infants, children and adults. Psychological and neurobiological experiments have given motivation to suggest that learning benefits from specific patterns of spacing of exposure and retention. According to Thalheimer [11], three or more repetitions are needed to ensure learning and spacing of exposures and spacing of retentions should be about equal and match the time required for remembering. According to Kandel [12], to activate genes establishing long-term memory stimulation of synapses can be triggered by 4-5 spaced puffs of serotonin. According to Fields [13], at least three action potentials separated with at least 10 minutes can activate a gene for long-term memory formation in a synapse leading it to produce required proteins for about 30 minutes. By exposing marine snail to four brief trains for four days could generate memories that lasted weeks [12].

A child in age of 2-30 months hears 12815 words per day from all adults, and there are 520 conversational turns per day for a 24-month-old child in a typical family [14]. Number of daily vocalizations is for a 12-month-old 10001500 vocalizations, for a 24-month-old 13002200 vocalizations, for a 36-month-old 16002700 vocalizations, and for a 48-month-old 17002700 vocalizations [14]. When considering 17-29year-olds, a man speaks 15669 words per day and a woman 16215 words per day [15]. Weekly time usage pattern for children living in a family having computer with internet show that a 6-8-year-old spent about $33 \mathrm{~h} 55 \mathrm{~min}$ in school, $2 \mathrm{~h} 26 \mathrm{~min}$ for additional studying, and furthermore $1 \mathrm{~h} 28 \mathrm{~min}$ in reading, $12 \mathrm{~min}$ in being read to and $1 \mathrm{~h} 8 \mathrm{~min}$ in computer activities, where as a 15-17-year-old spent $30 \mathrm{~h} 21 \mathrm{~min}$ in school, $5 \mathrm{~h}$ $20 \mathrm{~min}$ for additional studying, and furthermore 58 $\mathrm{min}$ in reading, $0 \mathrm{~min}$ in being read to and $4 \mathrm{~h} 5 \mathrm{~min}$ in computer activities [16].

A student with an average score in reading test reads 12,9 minutes per day or 601000 words per year [19] whereas a student with an excellent score reads 90,7 minutes per day or 4733000 words per year [19]. Reading speed for population in general is about 200 words per minute [20] and for sufficient comprehension at least about 200 words per minute is suggested [21], and with an average sentence length below 20 words [22] this results in at least 10 sentences per minute. Based on previous research it has been concluded estimates that a student can yearly adopt 1000 new word families [3] or 20003500 new words [17] or 3000 new words [18].

Concerning amount of arriving and departing hyperlinks, in the World Wide Web, a mean indegree is 6,10 and a mean out-degree is 38,11 [23], whereas in the Wikipedia a mean in-degree is 20,63 and a mean outdegree is 20,63 , and a median indegree is 4 and a median out-degree is 12 [24]. Relation between the number of directed links $\mathrm{L}$ and articles $\mathrm{N}$ in the Wikipedia has been suggested to be approximately $\mathrm{L}=\mathrm{N}^{1,4}$ [25]. Rodero-Merino et al. [26] showed experimentally that coverage of a random walk in small-world network grows faster when the average degree of network is higher and also that an average search length grows linearly with the network size and the bigger the average degree the shortest the searches are. According to an experiment of full hyperlink network of the Wikipedia on 3 March 2008 [27] on average 4,573 traversals of hyperlinks are needed to get from any article to any other article. Correspondingly in a mailing experiment in the USA with 296 persons the number of relationship steps connecting two persons was in the range 4,6-6,1 [28], and in Facebook social network with 721 million users and 68,7 billion links between them the average number of relationship steps was 4,74 [29].

\section{Method}

Content of the Wikipedia online encyclopedia can be quite revolutionarily edited by anyone and despite some skepticism vandalism has not prevented building relatively extensive and educationally reliable knowledge content often supplied with some convincing references and importantly all edits are saved to a log thus enabling a convenient access and possibility to revert to any previous version of an article [30] [31]. There is a need to develop educational resources that can be flexibly updated, shared and personalized and we think that the Wikipedia and its related sibling projects can inherently offer promising resources for trying to find most optimal processes for building and exploring knowledge structures in learning. Our work focuses especially on the biggest language edition English Wikipedia (http://en.wikipedia.org) containing over 4,3 million articles (in July 2013).

Each encyclopedic article of the Wikipedia can be considered to represent a concept that is the title entry of the article. Text of an article is typically supplied with hyperlinks to related other articles and thus hyperlink network of the Wikipedia can be considered to form a conceptual network. Besides establishing connectivity from start concept to end concept of hyperlink, each hyperlink is typically surrounded by a sentence in the article text of start concept that offers a brief written definition about the relationship between the connected concepts.

We think that already at the moment the Wikipedia basically contains so much useful knowledge that it could possibly cover a majority of all those situations dealing with a need of factual knowledge that a student can encounter during all his 
school years. However, this useful knowledge is not possibly organized and presented currently in the most optimal form to support independent cumulative adoption of knowledge that addresses student's previous knowledge and personal needs as well as to help identifying the most essential content for current learning topic and to encourage inductive and deductive reasoning with sufficiently spaced and repeated exposure and retention.

Therefore we think that there is a great potential for education in the knowledge contained already now in the Wikipedia but to enable better learning opportunities relying on the Wikipedia the research community should invest on more analysis about the properties of the Wikipedia and to develop computational methods that let to transform its knowledge to various forms of representation to address personalized educational needs of a student.

Motivated by our earlier work [32] and previous research that has identified emergence of smallworld topology in human brain networks [1] and in the Wikipedia [2] as well as indications about scalefree properties possibly in human brain networks [38] and more surely in the Wikipedia [39], we propose a method for cumulative adoption of vocabulary supported by representations of vocabulary in knowledge structures that are based on a small-world network (and possibly a scale-free version being the most preferable). We think that due to properties of small-world network and scale free network emerging inherently in various instances of nature, it is possible that learning of new knowledge can get useful support if new pieces of knowledge can be added to learner's previous knowledge entities in mind in a process that can be represented by building a small-free small-world network and through its modification and exploration.

We think that instead of just one scale-free small-world network there can be a great number of diverse parallel and partially overlapping and multidimensional small-world networks that can be used at the same time to represent knowledge both in educational material, such as texts, and in the learner's mind. We think that among students there are large individual differ ences in student's mental scale-free small-world networks representing his previous knowledge entity. Therefore to make new pieces of knowledge to become sufficiently fit into previous knowledge entity of student during learning process it is useful to offer personalized forms of representation of educational material.

With our method educational material is presented to student with cumulative conceptual networks based on hyperlink network of Wikipedia connecting concepts of vocabulary about current learning topic. Personalization of educational material is carried out by alternating the distribution of enabled hyperlinks connecting concepts belonging to current vocabulary according to requirements of learning objective, learning context and learner's knowledge. So far our method accepts only nouns to vocabularies since hyperlinks in the Wikipedia are typically defined to connect nouns but also other part-of-speech could be possibly exploited with a resembling approach.

Thus for life-long-learning an ultimate aim can be to reach a maximal coverage of the conceptual scale-free small-world networks representing all human knowledge and besides that even some personal contribution could be done to supplement this heritage of human knowledge through own writings and other forms of conveying new knowledge to the community. On the other hand, we think that all knowledge entities can been seen to consist of a complex collection of interconnected, overlapping and nested scale-free smallworld networks so that each separate new learning topic can be considered to be learned as an own specific scale-free small-world network that becomes gradually more and more connected also to other scale-free small-world network structures held already so far in the mind of student.

When creating a hyperlink network of vocabulary based on hyperlink network of the Wikipedia we suggest extracting a relation statement for each hyperlink of the Wikipedia from sentence surrounding hyperlink anchor of end concept in article text of start concept. For example for a hyperlink pointing from concept $\mathrm{Mu}$ sic to concept Art one relation statement from article text of start concept Music is "Music is an art form whose medium is sound and silence." (here hyperlink anchor underlined). We suggest that during exploration in hyperlink network of vocabulary when student traverses a hyperlink between concepts learning of this relationship is supported by showing to the student a relation statement corresponding to this hyperlink. Eventually a learning session consists of a chain of traversed hyperlinks and their relation statements that can be guided to proceed in a sequential process having tailored variation and repetition computed based on theory of spaced learning, as discussed in our previous work [32].

To enable implementing educational technology for practical educational activities for students we have carried out empirical experiments to try to identify some constraints of conceptual scale-free small-world networks and to better understand behavior of their properties. Thus besides developing a computational method for exploiting conceptual scale-free small-world networks to manage and explore educational material we now also report some preliminary findings of experiments about the properties of conceptual scale-free small-world networks that we have generated based on hyperlink network of the Wikipedia connecting concepts of vocabulary about current learning topic. 


\section{Experiment}

English Vocabulary Profile is a database aiming to represent all words and phrases learners know at each of six levels of Common European Framework of Reference for Languages (CEFRL) [33]. Table 1 shows properties of conceptual networks that we generated based on hyperlink network of the Wikipedia (as of June-July 2013) between concepts retrieved from English Vocabulary Profile (http://vocabulary.englishprofile.org/dictionary// word-list/uk/a1_c2/A) for cumulatively growing vocabularies corresponding to each of six language ability levels ranging from A1 to $\mathrm{C} 2$. A full listing of these conceptual networks is available in publication [41].

At the highest language ability level $\mathrm{C} 2$ we have the most extensive vocabulary that we call as vocabulary $\mathrm{A} 1 \& \mathrm{~A} 2 \& \mathrm{~B} 1 \& \mathrm{~B} 2 \& \mathrm{C} 1 \& \mathrm{C} 2$ (i.e. including all six cumulative vocabularies of consecutive language ability levels A1, A2, B1, B2, C1 and $\mathrm{C} 2$ together) and we identified that it contains 15715 unique language items (words or phrases) that include 3710 unique nouns (we considered common nouns only). Then we wanted to identify all possible hyperlinks that are connecting these 3710 unique nouns in hyperlink network of the Wikipedia and we found 25153 unique hyperlinks so that they actually connected 2878 unique nouns of these 3710 unique nouns. Therefore it seems that at language ability level $\mathrm{C} 2$ the Wikipedia can offer interconnected linkage for about 77,6 percent (2878/3710) of nouns belonging to current noun vocabulary. Furthermore, among these 2878 unique nouns 2635 occur as a start concept and 2310 occur as an end concept in connecting hyperlinks. According to our calculations each of these 2878 unique nouns of vocabulary $\mathrm{A} 1 \& \mathrm{~A} 2 \& \mathrm{~B} 1 \& \mathrm{~B} 2 \&$ $\mathrm{C} 1 \& \mathrm{C} 2$ has an average value of 8,7 departing unique hyperlinks and a median value of 5 departing unique hyperlinks and an average value of 8,7 arriving unique hyperlinks and a median value of 5 arriving unique hyperlinks linking it to other unique nouns belonging to the same vocabulary $\mathrm{A} 1 \& \mathrm{~A} 2 \& \mathrm{~B} 1 \& \mathrm{~B} 2 \& \mathrm{C} 1 \& \mathrm{C} 2$. In the entity of 25153 unique hyperlinks it appeared that for 4824 hyperlinks there was another hyperlink going also into opposite direction and thus 2412 connections can be considered bidirectional.

In Table 1 when proceeding to a vocabulary that is one level higher the increasing Wikipedia linkage does not originate only from the latest difference in vocabulary levels but it can partly originate also from concepts belonging to much earlier vocabulary levels and emerging to Wikipedia linkage with a delay along with the latest vocabulary level (see details in [41]).

Since applying the hyperlink network of the Wikipedia for educational activities relies on those nouns that actually happen to exist in hyperlinks, we wanted to estimate the properties of the conceptual networks we have generated in respect to size of noun vocabulary that is actually available for browsing in the Wikipedia along unique hyperlinks connecting unique nouns of vocabulary.

By comparing growth of values in columns of Table 1 along language ability levels from A1 to C2 we approximated that the number of unique nouns in vocabulary is about 1,3 times the number of unique nouns in unique Wikipedia hyperlinks connecting unique nouns in vocabulary, and the number of unique language items (words or phrases) in vocabulary is about 4,3 times the number of unique nouns in vocabulary, and the number of unique Wikipedia hyperlinks connecting unique nouns in vocabulary is about 8,8 times the number of unique nouns in unique Wikipedia hyperlinks connecting unique nouns in vocabulary. Based on these dependencies we extrapolated to Table 1 coarse predicted estimated values to represent four additional cases in which the number of unique nouns in vocabulary reaches such levels that have been suggested in previous research to correspond to reasonable 95 percent level comprehension (30005000 or just 2000-3000 word families [3] [5]), a non-native adult (8000-9000 word families [4]), native adult (20000 word families [3]) and general vocabulary (well over 54000 word families in English [3]).

Brezina and Gablasova [34] estimated that about 46 percent of 3000 highest-ranking words of British National Corpus are nouns $(0,46 \approx 1 / 2,2)$ which is a greater ratio than a ratio based on our just mentioned approximation that there are 23 percent $(0,23 \approx 1 / 4,3)$ unique nouns in unique language items of a vocabulary. Anyway since Wikipedia hyperlinks connect now only nouns we assume that a student's explorations among 2878 unique nouns in 25153 unique hyperlinks connecting unique nouns of vocabulary $\mathrm{A} 1 \& \mathrm{~A} 2 \& \mathrm{~B} 1 \& \mathrm{~B} 2 \& \mathrm{C} 1 \& \mathrm{C} 2$ can at least indirectly offer a conceptual exposure and coverage of 2,2-4,3 times greater amount of unique language items (i.e., containing also other part-ofspeech than just nouns) meaning coverage of 626112522 unique language items. A student can gain this additional exposure for example by reading supplementing words in relation statements extracted from sentences surrounding hyperlink anchor in article text of start concept.

Therefore we suggest that hyperlink network of vocabulary $\mathrm{A} 1 \& \mathrm{~A} 2 \& \mathrm{~B} 1 \& \mathrm{~B} 2 \& \mathrm{C} 1 \& \mathrm{C} 2$ containing 2878 unique nouns with 25153 unique interconnecting hyperlinks can be considered to offer sufficient knowledge structure to represent relatively reliably conceptualization of everyday human vocabulary corresponding to reasonable 95 percent level comprehension (3000-5000 or just 2000-3000 word families [3] [5]) that is defined based on 
cumulative iterative collaborative building process of Wikipedia online encyclopedia.

We carried out random path explorations in hyperlink network of 25153 unique hyperlinks connecting 2878 unique nouns of vocabulary $\mathrm{A} 1 \& \mathrm{~A} 2 \& \mathrm{~B} 1 \& \mathrm{~B} 2 \& \mathrm{C} 1 \& \mathrm{C} 2$ so that any hyperlink can be traversed in both actual linking direction and opposite direction and all explorations were started from concept Human (Human had the highest number of occurrences as a start/end concept of hyperlink, 227 times). A random path of 1000 steps visited 688 unique concepts (24 percent) of 2878 unique concepts and 50 percent of visits stayed among 202 unique concepts. Similarly a random path of 10000 steps visited 2025 unique concepts (70 percent) of 2878 unique concepts and 50 percent of visits stayed among 398 unique concepts, and a random path of 100000 steps visited 2770 unique concepts (96 percent) of 2878 unique concepts and 50 percent of visits stayed among 454 unique concepts. It was interesting to note that with a sufficiently large number of steps in random path explorations concept Human gained highest number of visits and this seems to indicate that concept
Human has a central role in defining conceptual connectivity of hyperlink network.

These results seem to indicate that in hyperlink network of vocabulary exploration relying heavily on random choices of student without systematic guidance can lead to relatively limited pedagogic gain due to visiting only limited subsection of all unique concepts and their unique connecting hyperlinks. Thus we suggest that pedagogically rewarding exploration in hyperlink network of vocabulary should actively exploit traversing the shortest paths connecting pairs of unique concepts of vocabulary. We think that in adoption of new knowledge the learner benefits from an opportunity to see intuitively the shortest connectivity between pieces of knowledge thus helping contextually to filter out less relevant things that might disturb concentration by excessive cognitive load, and using the shortest paths enables also highlighting clustering structure of conceptual relationships to the student and generating a systematic efficient process to traverse in hyperlink network of vocabulary with an extensive diverse coverage.

Table 1. Properties of conceptual networks generated based on hyperlink network of the Wikipedia between concepts for cumulative vocabularies of six language ability levels of English Vocabulary Profile ranging from $\mathrm{A} 1$ to $\mathrm{C} 2$

\begin{tabular}{|l|l|l|l|l|}
\hline $\begin{array}{l}\text { Vocabulary of language ability } \\
\text { level reached so far (predicted* } \\
\text { = only extrapolated estimates) }\end{array}$ & $\begin{array}{l}\text { Unique language items } \\
\text { (words or phrases) in } \\
\text { vocabulary }\end{array}$ & $\begin{array}{l}\text { Unique nouns } \\
\text { in vocabulary }\end{array}$ & $\begin{array}{l}\text { Unique Wikipedia } \\
\text { hyperlinks connecting } \\
\text { unique nouns in } \\
\text { vocabulary }\end{array}$ & $\begin{array}{l}\text { Unique nouns in unique } \\
\text { Wikipedia hyperlinks } \\
\text { connecting unique nouns in } \\
\text { vocabulary }\end{array}$ \\
\hline A1 & 785 & 305 & 1007 & 248 \\
\hline A1\&A2 & 2382 & 880 & 3868 & 706 \\
\hline A1\&A2\&B1 & 5327 & 1761 & 9566 & 1374 \\
\hline A1\&A2\&B1\&B2 & 9502 & 2707 & 17448 & 2121 \\
\hline A1\&A2\&B1\&B2\&C1 & 11908 & 3198 & 21410 & 2470 \\
\hline A1\&A2\&B1\&B2\&C1\&C2 & 15715 & 3710 & 25153 & 2878 \\
\hline $\begin{array}{l}3000-5000 \text { unique nouns } \\
\text { (reasonable 95 percent level } \\
\text { comprehension), predicted* }\end{array}$ & $12900-21500^{*}$ & $3000-5000$ * & $20308-33846^{*}$ & $2308-3846^{*}$ \\
\hline $\begin{array}{l}8000-9000 \text { unique nouns (non- } \\
\text { native adult), predicted* }\end{array}$ & $34400-38700^{*}$ & $8000-9000$ * & $54154-60923^{*}$ & $6154-6923^{*}$ \\
\hline $\begin{array}{l}20000 \text { unique nouns (native } \\
\text { adult), predicted* }\end{array}$ & $86000^{*}$ & $20000^{*}$ & $135385^{*}$ & $15385^{*}$ \\
\hline $\begin{array}{l}54000 \text { unique nouns (general } \\
\text { vocabulary), predicted }\end{array}$ & $232200^{*}$ & $54000^{*}$ & $365538^{*}$ & $415388^{*}$ \\
\hline
\end{tabular}

We suggest that to support adoption of vocabulary a student's guided exploration in hyperlink network of vocabulary could proceed pedagogically rewardingly if exploration of the shortest paths gradually moves to cover new concepts related to concepts that have been adopted already earlier. On coarser level of granularity this gradual moving can be implemented by moving from vocabulary $\mathrm{A} 1$ to $\mathrm{A} 1 \& \mathrm{~A} 2$ and then from vocabulary $\mathrm{A} 1 \& \mathrm{~A} 2$ to $\mathrm{A} 1 \& \mathrm{~A} 2 \& \mathrm{~B} 1$ and so on. On finer level of granularity the guided exploration should gradually introduce new concepts belonging to current vocabulary and its most related subset of concepts concerning current learning topic while still also helping to refresh previously adopted concepts, with sequential tailored variation and repetition computed based on theory of spaced learning (see details in [32]).

We also suggest that these new concepts should particularly include the highest-ranking concepts of the topics that are intended to be learned so that exploration in hyperlink network of vocabulary could be performed especially by traversing the shortest paths between the highest-ranking concepts of previously adopted concepts and the highestranking concepts of new concepts. In addition we suggest that, when available, parallel alternative shortest paths should be traversed between pairs of 
concepts to learn better the diversity of conceptual relations. With these suggestions we expect to establish efficient connectivity covering old and new concepts relying on dominant concept clusters of hyperlink network shown to student and that could then be also easier to conceptualize by the student.

We suggest that according to the needs of the learner new cumulative sets of vocabularies along gradually increasing adoption of new knowledge can be gained by generating high-frequency word lists from suitable text samples concerning intended learning topic or for example retrieving a desired set of words from resources such as British National Corpus [35].

We analyzed a sample of 102 Wikipedia articles selected to match 102 highest-ranking terms in texts generated by students (see details in [41]). These 102 articles had together hyperlinks to 20512 end concepts of which 14907 were unique and an article had on average 201 (median value 152) departing hyperlinks (as of 3 March 2008). When analyzing all 422 unique hyperlinks existing between these 102 Wikipedia articles (as of 3 March 2008) we found out that each start concept of a hyperlink had on average 4,1 (median value 3,5) different end concepts. Furthermore among all hyperlinks between these 102 Wikipedia articles (as of 3 March 2008) we indentified that there were on average 1,5 (median value 1) parallel hyperlinks (i.e. a certain end concept having more than one hyperlink anchors in article text of start concept) from each start concept to its end concept. For example, an article having two departing unique hyperlinks will on average have one of these two unique hyperlinks duplicated $(1,5 \times 2=3)$. In addition in all 422 unique hyperlinks existing between the set of 102 Wikipedia articles in the article text of start concept the end concept was mentioned on average 7,4 (median value 3) different times. On the other hand we indentified that in the article text of each 102 articles on average 21,3 (median 20) different concepts corresponding to other 101 article titles were mentioned (i.e. resembling end concept).

Thus based on this sample of 102 articles it seems that when considering a noun vocabulary interconnected by Wikipedia hyperlinks, on average Wikipedia article has 1,5 hyperlink anchors for each hyperlink and the end concept of each hyperlink occurs 7,4 times in article text of start concept. Furthermore while about 4 percent $(4,1 / 101)$ of concepts belonging to vocabulary can be actually reached via hyperlink from Wikipedia article it appears that about 21 percent $(21,3 / 101)$ of concepts belonging to vocabulary are anyway mentioned in article text of an average Wikipedia article, meaning that the number of potential relationships becomes multiplied with about $5(0,21 / 0,04)$.

These results suggest that besides actually existing unique hyperlinks between concepts of a vocabulary and possible exploitation of parallel hyperlinks there exists a passive potential to extend current linking by establishing additional supportive cross-linking between all occurrences of concepts of vocabulary in all Wikipedia article texts of concepts of vocabulary. These findings suggest concerning vocabulary $\mathrm{A} 1 \& \mathrm{~A} 2 \& \mathrm{~B} 1 \& \mathrm{~B} 2 \& \mathrm{C} 1 \& \mathrm{C} 2$ that hyperlink network which we so far managed to get to contain 2878 unique nouns with 25153 unique interconnecting hyperlinks can be extended progressively to contain much more hyperlinks, and using multiplication factors (1,5; 7,4 and 5) motivated above leads to an estimated range of 37730-186132 hyperlinks. By generating these supplementing hyperlinks we expect to increase diversity of linkage thus offering extended variation in exposure and coverage of a student's exploration in hyperlink network to adopt conceptual relationships and knowledge in general.

We carried out experiments to identify how the shortest paths in hyperlink network of vocabulary evolve when observed vocabulary is cumulatively expanded thus introducing new interconnecting hyperlinks and intermediary concepts that enable emergence of gradually shorter paths between pairs of concepts of vocabulary as well as increase in the number of parallel alternative paths. We experimented with vocabularies ranging from vocabulary A1 with 1007 unique interconnecting hyperlinks to vocabulary $\mathrm{A} 1 \& \mathrm{~A} 2 \& \mathrm{~B} 1 \& \mathrm{~B} 2 \& \mathrm{C} 1 \& \mathrm{C} 2$ with 25153 unique interconnecting hyperlinks and the results - generated with Yen's algorithm of top k shortest loopless paths [40] - seemed to support suggested pedagogic gains of using the shortest paths to guide educational exploration for adoption of new knowledge.

For example we analyzed how the available shortest paths evolve between start concept "question" and end concept "school" when expanding observed vocabulary cumulatively from $\mathrm{A} 1$ to $\mathrm{A} 1 \& \mathrm{~A} 2 \& \mathrm{~B} 1 \& \mathrm{~B} 2 \& \mathrm{C} 1 \& \mathrm{C} 2$. With vocabulary A1 the shortest paths require traversing eight consecutive hyperlinks and there is only one path of this length: question $->$ problem $->$ business -> restaurant $\rightarrow$ food $\rightarrow$ supermarket $->$ book $->$ homework $\rightarrow$ school. With vocabulary A1\&A2 the length of the shortest path has decreased to three hyperlinks and again there is only one path of this length: question -> quiz ->game -> school. With vocabularies bigger than A1\&A2 the length of the shortest path does not anymore decrease from three hyperlinks but new alternative parallel paths emerge thus introducing diversity to express the characteristics of relationship of concepts (please note that those shortest paths found with smaller vocabularies remain available also with bigger vocabularies). With vocabulary A1\&A2\&B1 two new alternative parallel paths emerge including question $\rightarrow$ grammar $\rightarrow$ education $\rightarrow$ school and 
question -> information -> education -> school, and with vocabulary $\mathrm{A} 1 \& \mathrm{~A} 2 \& \mathrm{~B} 1 \& \mathrm{~B} 2$ five new paths include question $\rightarrow$ philosophy $\rightarrow$ psychology $\rightarrow$ school, question $\rightarrow$ philosophy $\rightarrow$ government $\rightarrow$ school, question $\rightarrow$ theory $\rightarrow>$ education $->$ school, question $\rightarrow$ theory $\rightarrow$ psychology $\rightarrow$ school and question $\rightarrow$ concept $\rightarrow$ psychology $\rightarrow>$ school. With vocabulary $\mathrm{A} 1 \& \mathrm{~A} 2 \& \mathrm{~B} 1 \& \mathrm{~B} 2 \& \mathrm{C} 1$ one new alternative parallel path emerges including question - > proposition -> psychology -> school but vocabulary $\mathrm{A} 1 \& \mathrm{~A} 2 \& \mathrm{~B} 1 \& \mathrm{~B} 2 \& \mathrm{C} 1 \& \mathrm{C} 2$ does not introduce any more new paths (i.e. vocabulary $\mathrm{A} 1 \& \mathrm{~A} 2 \& \mathrm{~B} 1 \& \mathrm{~B} 2 \& \mathrm{C} 1 \& \mathrm{C} 2$ offers nine parallel paths) which can possibly even indicate that already with this size of vocabulary some kind of saturation has been reached in formation of somewhat optimal connectivity between these two concepts of human knowledge in respect to the shortness of paths and diversity of parallel paths.

\section{Discussion and future work}

We have now explained our experiments creating estimates about the sizes of hyperlink networks that can match with language ability levels from A1 to C2 of English Vocabulary Profile, and also estimates about the sizes of hyperlink networks that can match with sizes of vocabularies covering language usage needs for reasonable 95 percent level comprehension, non-native adults, native adults and general vocabulary. We have also estimated how already hyperlink network of vocabulary A1\&A2\& B1\&B2\&C1\&C2 containing 2878 unique nouns with 25153 unique interconnecting hyperlinks can be extended to offer much more hyperlinks based on article texts defining unused potential conceptual relationships and possible exploitation of parallel hyperlinks. We have also experimentally identified relatively limited coverage gained with random paths in hyperlink network of vocabulary and thus we have suggested using the shortest paths to guide educational exploration for adoption of new knowledge, and with cumulatively growing vocabularies the length of the shortest paths can usefully decrease and alternative parallel paths offering diversity can be gained. We do not know any previous research proposing same kind of approach and results that we have presented here (see details in [41]) and we hope that our suggestions can open promising new perspectives to learning. Based on our experiments we next explain some further suggestions for educational use of hyperlink network of vocabulary and we hope these ideas can offer inspiration for future work in both on research agenda and in real-life application to support personalized learning.

It is pedagogically useful that when observing the shortest paths to two opposite directions between a pair of concepts there often emerges two different routings offering new perspectives. For example with vocabulary $\mathrm{A} 1 \& \mathrm{~A} 2 \& \mathrm{~B} 1 \& \mathrm{~B} 2 \& \mathrm{C} 1 \& \mathrm{C} 2$ from concept "love" to concept "memory" the shortest paths have two hyperlinks and there is only one path of this length: love $->$ psychology $\rightarrow$ memory, and from concept "memory" to concept "love" the shortest paths have three hyperlinks and there are three alternative parallel paths of this length including memory $\rightarrow>$ psychology $\rightarrow$ emotion $->$ love, memory $\rightarrow$ psychology $\rightarrow$ motivation $\rightarrow>$ love and memory $\rightarrow$ learning $\rightarrow$ emotion $\rightarrow$ love. Besides identifying the shortest paths in both directions between a pair of concepts we suggest that additional pedagogic potential of diversity and possibly even shorter paths become available when identifying the shortest paths in hyperlink network of vocabulary also so that any hyperlink can be traversed in both actual linking direction and opposite direction. When enabling these bidirectional hyperlink traversals in hyperlink network of vocabulary $\mathrm{A} 1 \& \mathrm{~A} 2 \& \mathrm{~B} 1 \&$ $\mathrm{B} 2 \& \mathrm{C} 1 \& \mathrm{C} 2$ between concepts "love" and "memory" the shortest paths have two hyperlinks and there are three alternative parallel paths of this length: love $\rightarrow$ psychology $\rightarrow$ memory, love $\rightarrow$ loneliness $\rightarrow>$ memory and love $->$ mind $\rightarrow>$ memory.

We think that pedagogically useful exploration in hyperlink network of vocabulary could benefit from exploring especially those shortest paths that exist between the highest-ranking hyperlinked concepts and strongly rising hyperlinked concepts of vocabulary, and some of them are shown in Table 2 for cumulative vocabularies of six language ability levels of English Vocabulary Profile ranging from A1 to $\mathrm{C} 2$ (for common nouns only).

Column High of Table 2 lists some of the highest-ranking hyperlinked concepts (occurrences indicated in parenthesis), i.e. those concepts that have the highest number of unique departing hyperlinks (in case of highest-ranking as being a start concept) or unique arriving hyperlinks (in case of highest- ranking as being end concept). Column Rising of Table 2 lists some of strongly rising hyperlinked concepts, i.e. concepts that seem to strongly rise in ranking position from previous smaller vocabulary to current bigger vocabulary in respect to the number of departing or arriving unique hyperlinks (for example which of the concepts belonging to vocabulary A1 seem to get among the biggest increases in ranking position when observing these same concepts again in vocabulary A1\&A2). We created shown list of rising concepts (change in ranking position indicated in parenthesis, suffix -s indicating shared ranking position) by browsing highest-ranking concepts in decreasing order and selected such concepts which increased their ranking position by at least value 0,01 when for all vocabularies the ranges of ranking values had been first transformed to an equal range of closed interval from zero to one (i.e. $[0,1]$ ). 
Similarly as in Table 1 for English Vocabulary Profile, Table 3 shows properties of conceptual networks that we generated based on hyperlink network of the Wikipedia (as of June-July 2013) between concepts retrieved from Oxford Wordlist [36] [37] (http://www.oxfordwordlist.com/pages/ search.asp) for partially cumulatively growing vocabularies corresponding to each of five school levels ranging from Preparatory to Year 4 (for common nouns only). Concepts were retrieved so that the only setting we varied was school year, thus keeping settings concerning gender, language, indigenousness, school setting, location and text type always at option "any", and furthermore nouns were extracted based on co-occurrence among nouns of C2 vocabulary of English Vocabulary Profile. A full listing of these conceptual networks is available in publication [41].

At the highest school level Year 4 we identified 1445 unique nouns and when we wanted to identify all possible hyperlinks that are connecting these 1445 unique nouns in hyperlink network of the Wikipedia we found 6759 unique hyperlinks so that they actually connected 1072 unique nouns of these 1445 unique nouns. Therefore it seems that at school level Year 4 the Wikipedia can offer interconnected linkage for about 74,3 percent $(1073 / 1445)$ of nouns belonging to current noun vocabulary. Furthermore, among these 1072 unique nouns 971 occur as a start concept and 898 occur as an end concept in connecting hyperlinks. According to our calculations each of these 1073 interconnected nouns at school level Year 4 has an average value of 7,0 departing unique hyperlinks and a median value of 5 departing unique hyperlinks and an average value of 7,5 arriving unique hyperlinks and a median value of 5 arriving unique hyperlinks linking it to other nouns belonging to same Year 4 noun vocabulary. In the entity of 6759 unique hyperlinks for 1416 hyperlinks there was another hyperlink going into opposite direction thus 708 connections can be considered bidirectional.

Similarly as in Table 2 for English Vocabulary Profile, Table 4 shows some of the highest-ranking hyperlinked concepts and strongly rising hyperlinked concepts of partially cumulative vocabularies of five school levels of Oxford Wordlist ranging from Preparatory to Year 4 (for common nouns only).

We think that a person's ability to adopt new knowledge based on the shortest paths between concepts is affected for example by the length of the shortest paths, the number of alternative parallel shortest paths and the number of different concepts belonging to intermediary concepts along paths. We think that among parallel paths those shortest paths that have the highest number of shared intermediary concepts and especially such intermediary concepts that occur most often among paths are important paths to define meaning of relationship between a pair of concepts. On the other hand to express diversity of meanings those shortest paths are important which have the most distinctive routing among parallel paths (i.e. minimizing sharing). Also longer paths than the shortest paths can complement meanings of conceptual relationships.

We think that to adopt new knowledge a successful pedagogical exploration in hyperlink network of vocabulary could possibly benefit from such mental processes of student that have resemblance to traversing average search paths in network. Thus we suggest that conceptualization in the student's mind could benefit from having such guided exploration in conceptual networks that enables many explorations that do not explore directly only the shortest paths between concepts but instead extend to cover also some sidetracks and even dead-ends.

Motivated by previous research showing that a small-world network of 10000 nodes has an average search path of 950 steps for an average degree of 10 and an average search path of 200 steps for an average degree of 30 [26] and that the Wikipedia has a mean out-degree of 20,63 (median value 12) [24], we thus coarsely estimate that in a hyperlink network of vocabulary $\mathrm{A} 1 \& \mathrm{~A} 2 \& \mathrm{~B} 1 \& \mathrm{~B} 2 \& \mathrm{C} 1 \& \mathrm{C} 2$ having an average out degree of 8,7 (median value 5) and containing 2878 unique nouns to enable the student to at least weakly conceptualize a single relationship between a pair of concepts could possibly require exploring about 300 steps in the hyperlink network of vocabulary. Since previous research showed that in the Wikipedia on average 4,573 hyperlink steps are between a pair of concepts [27], and similarly in Facebook social network the average number of relationship steps between two users is 4,74 [29], our coarse estimate of exploring 300 steps is about 66 times the average length of the shortest path between a pair of concepts in a hyperlink network of vocabulary.

It thus seems that the student's conceptualization of conceptual relationships can require many times more exploration steps in the hyperlink network than belong to exploring just the shortest paths. On the other hand, it is possible that when traversing one exploration path several concepts that become encountered along the path can be cumulatively conceptualized in parallel, and it is also possible that the number of steps needed in later explorations can decrease as some kind of memories about previous explorations help to guide later explorations.

Since earlier research estimates that a child is daily exposed to hear about 12815 words [14] and produces 1000-2700 vocalizations [14], and an adult speaks daily about 15669-16215 words [15], it seems to us that human learning ability apparently can easily manage knowledge adoption at least through listening at a daily rate of about 12815-16215 words. 
Table 2. - Some of the highest-ranking hyperlinked concepts and strongly rising hyperlinked concepts for cumulative vocabularies of six language ability levels of English Vocabulary Profile ranging from Al to C2

\begin{tabular}{|c|c|c|c|c|c|c|c|c|c|c|c|c|c|}
\hline \multirow{2}{*}{\multicolumn{5}{|c|}{ English Vocabulary Profile: A1 }} & \multicolumn{4}{|c|}{ English Vocabulary Profile: A1-A2 } & \multicolumn{5}{|c|}{ English Vocabulary Profile: A1-B1 } \\
\hline & & & & & \multicolumn{2}{|c|}{ As start concept } & \multicolumn{2}{|c|}{ As end concept } & \multicolumn{3}{|c|}{ As start concept } & \multicolumn{2}{|c|}{ As end concept } \\
\hline & Rising & High & Rising & High & Rising & High & Rising & \begin{tabular}{l|l} 
High & $\mathrm{R}$ \\
\end{tabular} & Rising & & High & Rising \\
\hline \multicolumn{2}{|c|}{ food (22) } & N/A & animal (21) & N/A & food (38) & $\begin{array}{l}\text { water }(9.5 \mathrm{~s} \mid \mathrm{w} \\
->2)\end{array}$ & water (48) & $\begin{array}{l}\operatorname{sun}(11.5 \mathrm{~s} \\
->5.5 \mathrm{~s})\end{array}$ & \begin{tabular}{l|l} 
human & ti \\
$(61)$
\end{tabular} & $\begin{array}{l}\text { time }(12 \\
>7)\end{array}$ & & $\begin{array}{l}\text { huma } \\
\text { n (68) }\end{array}$ & $\begin{array}{l}\text { science } \\
(20->6)\end{array}$ \\
\hline \multicolumn{2}{|c|}{ month (19) } & N/A & water (20) & $\mathrm{N} / \mathrm{A}$ & water (33) & $\begin{array}{l}\text { shoe } \\
(13.5 \mathrm{~s} \\
->5)\end{array}$ & animal (41) & $\begin{array}{l}\text { fruit }(9.5 \mathrm{~s} \\
->5.5 \mathrm{~s})\end{array}$ & $\begin{array}{l}\text { food } \\
(60)\end{array}$ & $\begin{array}{l}\text { book (15.5 } \\
>14)\end{array}$ & & $\begin{array}{l}\text { anima } \\
(67)\end{array}$ & $\begin{array}{l}\mid \begin{array}{l}\text { music } \\
(32 \\
->18.5 s)\end{array} \\
\end{array}$ \\
\hline \multicolumn{2}{|c|}{$\begin{array}{l}\text { supermarket } \\
\text { p party (18) }\end{array}$} & N/A & food (17) & $\mathrm{N} / \mathrm{A}$ & toy (30) & $\begin{array}{l}\text { game } \\
(18.5 \mathrm{~s} \\
->7.5 \mathrm{~s})\end{array}$ & food (34) & $\begin{array}{l}\text { television } \\
(19.5 \mathrm{~s} \\
->7.5 \mathrm{~s})\end{array}$ & \begin{tabular}{l|l} 
entertai & $p$ \\
nment & $\mathrm{k}$ \\
$(57)$ & -3
\end{tabular} & $\begin{array}{l}\text { painting; } \\
\text { kitchen (15 } \\
>15.5 \mathrm{~s})\end{array}$ & & \begin{tabular}{|l} 
Water \\
$(66)$
\end{tabular} & $\begin{array}{l}\text { plant (32 } \\
->22.5 \mathrm{~s})\end{array}$ \\
\hline \multicolumn{2}{|c|}{$\begin{array}{l}\text { plant; bread; } \\
\text { meal (16) }\end{array}$} & $\mathrm{N} / \mathrm{A}$ & fish; rice (16) & N/A & $\begin{array}{l}\text { supermarke } \\
t_{i} \text { nature; } \\
\text { shoe (27) }\end{array}$ & $\begin{array}{l}\operatorname{soup}(8 \\
->7.5 \mathrm{~s})\end{array}$ & $\operatorname{wood}(32)$ & $\begin{array}{l}\text { sugar } \\
(11.5 \mathrm{~s} \\
->7.5 \mathrm{~s})\end{array}$ & \begin{tabular}{l|l} 
water & fr \\
$(56)$
\end{tabular} & $\begin{array}{l}\text { fruit }(20.5 \mathrm{~s} \\
>17.5 \mathrm{~s})\end{array}$ & & $\begin{array}{l}\text { earth } \\
(62)\end{array}$ & $\begin{array}{l}\operatorname{art}(22 \\
->22.5 \mathrm{~s})\end{array}$ \\
\hline \multicolumn{2}{|c|}{ soup (15) } & $\mathrm{N} / \mathrm{A}$ & $\begin{array}{l}\text { day; year; mil } \\
\text { (15) }\end{array}$ & illk $\mathrm{N} / \mathrm{A}$ & $\begin{array}{l}\text { soup; game } \\
(25)\end{array}$ & $\begin{array}{l}\text { bread (6 } \\
\text {->9.5s) }\end{array}$ & $\begin{array}{l}\text { fruit; sun } \\
\text { (29) }\end{array}$ & $\begin{array}{l}\text { bird }(19.5 \mathrm{~s} \\
->9)\end{array}$ & $\begin{array}{l}\text { transpo } \\
\text { it }(50)\end{array}$ & $\begin{array}{l}\text { artist (46.5 } \\
>21.5 \mathrm{~s})\end{array}$ & & $\begin{array}{l}\text { turke) } \\
(53)\end{array}$ & \begin{tabular}{l|l}
$y$ & business \\
$(36.5 \mathrm{~s}$ \\
$->28.5 \mathrm{~s})$
\end{tabular} \\
\hline \multicolumn{2}{|c|}{$\begin{array}{l}\text { water; house } \\
\text { (14) }\end{array}$} & $N / A$ & $\begin{array}{l}\text { month; fruit } \\
(14)\end{array}$ & $\mathrm{N} / \mathrm{A}$ & $\begin{array}{l}\text { month; } \\
\text { bread (24) }\end{array}$ & \begin{tabular}{l|l} 
time $(13.5 \mathrm{~s}$ & $\mathrm{su}$ \\
te & \\
$(2 \mathrm{e}$
\end{tabular} & $\begin{array}{l}\text { Sugar; } \\
\text { television } \\
\text { (26) }\end{array}$ & $\begin{array}{l}\text { meat }(13 \\
->11.5 \mathrm{~s})\end{array}$ & \begin{tabular}{|l|l} 
nature & s \\
$(46)$ & $>$
\end{tabular} & $\begin{array}{l}\text { sausage (3 } \\
>21.5 \mathrm{~s})\end{array}$ & & $\begin{array}{l}\text { scien } \\
\text { e (49) }\end{array}$ & $\mid \begin{array}{l}\text { compute } \\
r(41 \\
->31.5 s)\end{array}$ \\
\hline \multicolumn{2}{|c|}{ lunch (12) } & N/A & $\begin{array}{l}\text { sugar; sun } \\
(13)\end{array}$ & $\mathrm{N} / \mathrm{A}$ & $\begin{array}{l}\text { time; plant; } \\
\text { party (23) }\end{array}$ & $\begin{array}{l}\text { kitchen (40 bi } \\
->15.5 \mathrm{~s})\end{array}$ & bird (25) & $\begin{array}{l}\text { milk }(7 \\
->11.5 \mathrm{~s})\end{array}$ & $\begin{array}{l}\text { time } \\
(41)\end{array}$ & $\begin{array}{l}\text { sky; wind } \\
(20.5 \mathrm{~s} \\
>21.5 \mathrm{~s})\end{array}$ & & $\begin{array}{l}\text { food } \\
(45)\end{array}$ & \begin{tabular}{|c|} 
time $(26$ \\
$->31.5 \mathrm{~s})$
\end{tabular} \\
\hline \multicolumn{2}{|c|}{$\begin{array}{l}\text { fruit; time; } \\
\text { garden; } \\
\text { shoe (11) }\end{array}$} & $\mathrm{N} / \mathrm{A}$ & meat (12) & N/A & $\begin{array}{l}\text { book; red; } \\
\text { kitchen; } \\
\text { painting } \\
\text { (22) }\end{array}$ & $\begin{array}{l}\text { book } \\
(18.5 \mathrm{~s} \\
->15.5 \mathrm{~s})\end{array}$ & $\begin{array}{l}\text { meat; milk; } \\
\text { leather; fish } \\
\text { (24) }\end{array}$ & $\begin{array}{l}\text { paper (31 } \\
->20)\end{array}$ & $\begin{array}{l}\text { shoe } \\
(40)\end{array}$ & $\begin{array}{l}\text { pizza (26 } \\
>26.5 \mathrm{~s})\end{array}$ & & $\begin{array}{l}\text { wood } \\
\text { (44) }\end{array}$ & $\mid \begin{array}{l}\text { history } \\
78.5 \mathrm{~s} \\
->34.5 \mathrm{~s})\end{array}$ \\
\hline \multirow{2}{*}{\multicolumn{2}{|c|}{\begin{tabular}{|l|} 
day; year; \\
book; drink; \\
november; \\
game (10) \\
milk; grass; \\
tomato (9) \\
\end{tabular}}} & N/A & $\begin{array}{l}\text { cheese; tea; } \\
\text { sheep (11) }\end{array}$ & $\mathrm{N} / \mathrm{A}$ & meal (21) & $\begin{array}{l}\text { Wind } \\
(54.5 \mathrm{~s} \\
->20.5 \mathrm{~s})\end{array}$ & \begin{tabular}{|l|} 
light; \\
plastic; \\
temperature \\
; rice (23) \\
\end{tabular} & $\begin{array}{l}\text { radio } \\
(49.5 \mathrm{~s} \\
->26)\end{array}$ & $\begin{array}{l}\text { soup; } \\
\text { toy } \\
(37)\end{array}$ & $\begin{array}{l}\text { sea }(63.5 \mathrm{~s} \\
>30)\end{array}$ & & $\begin{array}{l}\text { sun } \\
(43)\end{array}$ & $\begin{array}{l}\text { physics } \\
(32 \\
->34.5 s)\end{array}$ \\
\hline & & N/A & $\begin{array}{l}\text { plant; time; } \\
\text { bird; horse; } \\
\text { television; } \\
\text { computer (10 }\end{array}$ & $\mathrm{N} / \mathrm{A}$ & $\begin{array}{l}\text { fruit; wind; } \\
\text { salad; sky } \\
\text { (20) }\end{array}$ & \begin{tabular}{l|l} 
fruit $(13.5$ \\
$\rightarrow>20.5 \mathrm{~s})$
\end{tabular} & insect (22) & $\begin{array}{l}\text { wine }(31 \\
->26)\end{array}$ & $\left|\begin{array}{l|}\text { technol } \\
\text { ogyi } \\
\text { mind } \\
(35)\end{array}\right|>$ & $\begin{array}{l}\text { meat }(36.5 \\
>30)\end{array}$ & & $\begin{array}{l}\text { religio } \\
\text { n (42) }\end{array}$ & \begin{tabular}{l|l|} 
languag \\
e $(66$ \\
$->40)$
\end{tabular} \\
\hline \multicolumn{5}{|c|}{ English Vocabulary Profile: A1-B2 } & \multicolumn{4}{|c|}{ English Vocabulary Profile: A.1-C1 } & \multicolumn{5}{|c|}{ English Vocabulary Profile: $\mathrm{A} 1-\mathrm{C} 2$} \\
\hline \multicolumn{3}{|c|}{ As start concept } & \multicolumn{2}{|c|}{ As end concept } & \multicolumn{2}{|c|}{ As start concept } & \multicolumn{2}{|c|}{ As end concept } & \multicolumn{5}{|c|}{\begin{tabular}{|l|l|} 
As start concept & As end concept \\
\end{tabular}} \\
\hline High & Rising & & High & Rising & High & Rising & High & Rising & High & Rising & High & & ising \\
\hline $\begin{array}{l}\text { human } \\
(98)\end{array}$ & $\begin{array}{l}\text { comp } \\
\text { scien } \\
(48.5 \\
->18 .\end{array}$ & $\begin{array}{l}\text { oetition; } \\
\text { ice } \\
\text { ss) }\end{array}$ & water (93) & $\operatorname{law}_{-10.5 \mathrm{~s})}$ & human (112) & $\underset{->21)}{\text { abuse (50 }}$ & $0 \mid \begin{array}{l}\text { water } \\
(102)\end{array}$ & $\begin{array}{l}\text { genetics } \\
(65 \\
->50)\end{array}$ & $\begin{array}{l}\text { human } \\
\text { (121) }\end{array}$ & $\begin{array}{l}\text { philoso } \\
\text { phy (74- } \\
>44)\end{array}$ & anime & & $\begin{array}{l}\text { war (65.5s } \\
>41)\end{array}$ \\
\hline $\begin{array}{l}f \circ o d \\
(78)\end{array}$ & $\begin{array}{l}\text { meat } \\
->18\end{array}$ & $5 \mathrm{~s})$ & animal (91) & $\begin{array}{l}\text { governme } \\
\text { nt }(50.5 \mathrm{~s} \\
->25.5 \mathrm{~s})\end{array}$ & food (86) & $\begin{array}{l}\text { evolution } \\
(69->38)\end{array}$ & \begin{tabular}{l|l} 
& $\begin{array}{l}\text { animal } \\
(100)\end{array}$
\end{tabular} & $\begin{array}{l}\text { medicine } \\
(70.5 \mathrm{~s}- \\
>53)\end{array}$ & food (93) & $\begin{array}{l}\text { cancer } \\
(80 \\
->58)\end{array}$ & $\begin{array}{l}\text { water } \\
(106)\end{array}$ & & $\begin{array}{l}\operatorname{logic}(116 \\
>82.5 s)\end{array}$ \\
\hline \begin{tabular}{|l} 
Water \\
(72)
\end{tabular} & $\begin{array}{l}\text { reaso } \\
(56.5 \\
->24)\end{array}$ & & human (90) & $\begin{array}{l}\text { language } \\
(40 \\
->34.5 s)\end{array}$ & water (82) & $\begin{array}{l}\text { oxygen }(56 \\
->39)\end{array}$ & $\begin{array}{l}56 \text { human } \\
(97)\end{array}$ & $\begin{array}{l}\text { crime }(84 \\
->59.5 \mathrm{~s})\end{array}$ & \begin{tabular}{|l} 
water \\
$(85)$
\end{tabular} & $\begin{array}{l}\operatorname{ship}_{-\rightarrow 70)}(94 \\
\end{array}$ & $\begin{array}{l}\text { earth } \\
\text { (101) }\end{array}$ & & $\begin{array}{l}\text { death (127 } \\
>88)\end{array}$ \\
\hline \begin{tabular}{|l|} 
enterta \\
inment \\
$(68)$
\end{tabular} & $\begin{array}{c}\text { crime } \\
->30 .\end{array}$ & $\begin{array}{l}5 \mathrm{~s}) \\
5 \mathrm{~s}\end{array}$ & earth (84) & $\begin{array}{l}\text { biology } \\
(44.5 \mathrm{~s} \\
->40)\end{array}$ & nature (75) & $\begin{array}{l}\text { life }(124 \\
->43)\end{array}$ & earth (94) & $\begin{array}{l}\text { statistics } \\
(90 \\
->65.5 s)\end{array}$ & $\begin{array}{l}\text { nature } \\
(79)\end{array}$ & $\begin{array}{l}\text { death } \\
(92 \\
\rightarrow>74)\end{array}$ & (98) & & $\begin{array}{l}\text { police (127 } \\
>95)\end{array}$ \\
\hline $\begin{array}{l}\text { transp } \\
\text { ort } \\
(66)\end{array}$ & $\begin{array}{l}\text { future } \\
->30 .\end{array}$ & $\begin{array}{l}(48.5 \mathrm{~s} \\
5 \mathrm{~s})\end{array}$ & $\begin{array}{l}\text { Carbon } \\
\text { dioxide (70) }\end{array}$ & $\begin{array}{l}\text { chemistry } \\
(50.5 \mathrm{~s} \\
->47)\end{array}$ & $\begin{array}{l}\text { entertainment } \\
\text { (71) }\end{array}$ & $\mid \begin{array}{l}\text { title }(77.5 \\
->64)\end{array}$ & \begin{tabular}{l|l}
5 & $\begin{array}{l}\text { mammal } \\
(91)\end{array}$
\end{tabular} & $\begin{array}{l}\text { aluminium } \\
(95.5 \mathrm{~s}- \\
>84)\end{array}$ & $\begin{array}{l}\text { entertain } \\
\text { ment (74) }\end{array}$ & $\begin{array}{l}\text { evaluati } \\
\text { on } \\
(100- \\
>81)\end{array}$ & & 2) & $\begin{array}{l}\text { profession } \\
(108 \\
>95)\end{array}$ \\
\hline \begin{tabular}{|l|} 
nature \\
(65)
\end{tabular} & $\begin{array}{l}\text { music } \\
->34)\end{array}$ & c $37.5 \mathrm{~s}$ & philosophy; & $\begin{array}{l}\text { disease } \\
(65.5 \mathrm{~s} \\
->51.5 \mathrm{~s})\end{array}$ & transport (70) & $\begin{array}{l}\text { rainforest } \\
(91.5 \mathrm{~s}- \\
>67)\end{array}$ & $\begin{array}{l}\text { philosoph } \\
y \text { (83) }\end{array}$ & $\begin{array}{l}\text { experimen } \\
\text { t }(117- \\
>93.5 \mathrm{~s})\end{array}$ & $\begin{array}{l}\text { transport } \\
(72)\end{array}$ & $\begin{array}{l}\text { invasion } \\
(117- \\
>82)\end{array}$ & & & $\begin{array}{l}\text { Contract } \\
(168 \\
>112)\end{array}$ \\
\hline $\begin{array}{l}\text { mind } \\
(52)\end{array}$ & $\begin{array}{l}\text { cultur } \\
>44)\end{array}$ & re (65- & religion (68) & $\begin{array}{l}\text { technolog } \\
y(50.5 \mathrm{~s} \\
->51.5 \mathrm{~s})\end{array}$ & $\begin{array}{l}\text { infrastructure } \\
\text { (64) }\end{array}$ & $\begin{array}{l}\text { bird }(124 \\
->79)\end{array}$ & \begin{tabular}{|l|l} 
protein \\
$(81)$
\end{tabular} & $\begin{array}{l}\text { blood } \\
(108 \\
->93.5 \mathrm{~s})\end{array}$ & $\begin{array}{l}\text { nutrition } \\
(68)\end{array}$ & $\begin{array}{l}\text { creativit } \\
\text { y (109- } \\
>87)\end{array}$ & law (c) & & $\begin{array}{l}\text { climate } \\
\text { change } \\
(148 \\
>112)\end{array}$ \\
\hline \begin{tabular}{|l|} 
techno \\
$\log y$ \\
$(48)$
\end{tabular} & $\begin{array}{l}\text { skin }( \\
->50)\end{array}$ & & $\begin{array}{l}\text { psychology } \\
\text { (65) }\end{array}$ & $\begin{array}{l}\text { society } \\
(56 \\
->55.5 \mathrm{~s})\end{array}$ & nutrition (63) & $\begin{array}{l}\text { cancer } \\
(143.5 \mathrm{~s} \\
->80)\end{array}$ & $\begin{array}{l}\text { religion } \\
(78)\end{array}$ & $\begin{array}{l}\text { child; } \\
\text { heart } \\
(108- \\
>101)\end{array}$ & mind (66) & $\begin{array}{l}\text { civilizati } \\
\text { on } \\
(155- \\
>100)\end{array}$ & $\begin{array}{l}\text { prot } \\
\text { reli } \\
(85)\end{array}$ & & $\begin{array}{l}\text { system } \\
(138 \\
>112)\end{array}$ \\
\hline $\begin{array}{l}\text { time; } \\
\text { shoe } \\
(47)\end{array}$ & $\begin{array}{l}\text { insect } \\
>50 \text { ) }\end{array}$ & t $65-$ & \begin{tabular}{|l|}
$\begin{array}{l}\text { culture; law } \\
(64)\end{array}$ \\
$(64)$
\end{tabular} & $\begin{array}{l}\text { knowledg } \\
\text { e; war } \\
(109.5 \mathrm{~s} \\
->59.5 \mathrm{~s})\end{array}$ & $\begin{array}{l}\text { globalization; } \\
\text { mind (58) }\end{array}$ & \begin{tabular}{l|l} 
& milk (91.5s \\
$->81)$
\end{tabular} & 5 s $\begin{array}{l}\text { psycholog } \\
\text { y; carbon } \\
\text { dioxide } \\
(76)\end{array}$ & g| trade (158 & $\begin{array}{l}\text { infrastruct } \\
\text { ure (65) }\end{array}$ & $\begin{array}{l}\text { ct } \begin{array}{l}\text { mask } \\
(133 \\
\rightarrow 112)\end{array} \\
\rightarrow>1\end{array}$ & $\begin{array}{l}\text { scien } \\
\text { carbo } \\
\text { dioxic } \\
(80)\end{array}$ & \begin{tabular}{l|l} 
nce; & $f$ \\
on & \\
ide & 1
\end{tabular} & $\begin{array}{l}\text { fear } \\
(168-> \\
121.5 \mathrm{~s})\end{array}$ \\
\hline $\begin{array}{l}\text { plant } \\
(45)\end{array}$ & $\begin{array}{l}\text { garde } \\
\text { writer } \\
->61 .\end{array}$ & $\begin{array}{l}n_{i} \\
r(56.5 \mathrm{~s} \\
5 \mathrm{~s})\end{array}$ & science (63) & $\begin{array}{l}\text { money } \\
(99.5 \mathrm{~s} \\
->65)\end{array}$ & shoe (54) & $\begin{array}{l}\text { death } \\
(143.5 \mathrm{~s} \\
->92)\end{array}$ & $\begin{array}{l}\text { turkey } \\
(75)\end{array}$ & $\begin{array}{l}\text { risk tool } \\
(139.5 \mathrm{~s}- \\
>116)\end{array}$ & $\begin{array}{l}\text { globalizat } \\
\text { ion (63) }\end{array}$ & $\begin{array}{l}\text { cloud } \\
(127 \\
->119)\end{array}$ & & & $\begin{array}{l}\text { mind } \\
(157.5 \mathrm{~s} \\
>121.5 \mathrm{~s})\end{array}$ \\
\hline
\end{tabular}


Table 3. - Properties of conceptual networks generated based on hyperlink network of the Wikipedia between concepts for partially cumulative vocabularies of five school levels of Oxford Wordlist ranging from Preparatory to Year 4.

\begin{tabular}{|l|l|l|l|l|}
\hline $\begin{array}{l}\text { Vocabulary of } \\
\text { school level } \\
\text { reached so far }\end{array}$ & $\begin{array}{l}\text { Unique language items } \\
\text { (words or phrases) in } \\
\text { vocabulary }\end{array}$ & $\begin{array}{l}\text { Unique } \\
\text { nouns in } \\
\text { vocabulary }\end{array}$ & $\begin{array}{l}\text { Unique Wikipedia hyperlinks } \\
\text { connecting unique nouns in } \\
\text { vocabulary }\end{array}$ & $\begin{array}{l}\text { Unique nouns in Wikipedia } \\
\text { hyperlinks connecting unique } \\
\text { nouns in vocabulary }\end{array}$ \\
\hline Preparatory & 1923 & 685 & 2511 & 505 \\
\hline Year 1 & 2364 & 811 & 2946 & 592 \\
\hline Year 2 & 3041 & 1008 & 4203 & 749 \\
\hline Year 3 & 4808 & 1412 & 6750 & 1051 \\
\hline Year 4 & 4949 & 1445 & 6759 & 1072 \\
\hline
\end{tabular}

Table 4. - Some of the highest-ranking hyperlinked concepts and strongly rising hyperlinked concepts for partially cumulative vocabularies of five school levels of Oxford Wor dlist ranging from Preparatory to Year 4.

\begin{tabular}{|c|c|c|c|c|c|c|c|c|c|c|c|c|c|}
\hline \multicolumn{4}{|c|}{ Oxford Wordlist: Preparatory } & \multicolumn{6}{|c|}{ Oxford Wordlist: Year 1} & \multicolumn{4}{|c|}{ Oxford Wordlist: Year 2} \\
\hline \multicolumn{2}{|c|}{ As start concept } & \multicolumn{2}{|c|}{ As end concept } & \multicolumn{3}{|c|}{ As start concept } & \multicolumn{3}{|c|}{ As end concept } & \multicolumn{2}{|c|}{ As start concept } & \multicolumn{2}{|c|}{ As end concept } \\
\hline High & Rising & High & Rising & \multirow{2}{*}{\multicolumn{2}{|c|}{\begin{tabular}{|l|} 
High \\
food (34)
\end{tabular}}} & Rising & \multirow{2}{*}{\multicolumn{2}{|c|}{\begin{tabular}{|l|} 
High \\
animal (58) \\
\end{tabular}}} & Rising & \multirow{2}{*}{$\begin{array}{l}\text { High } \\
\text { food (38) }\end{array}$} & \multirow{2}{*}{\begin{tabular}{|l} 
Rising \\
$\begin{array}{l}\text { meat (19.5s- } \\
>6)\end{array}$
\end{tabular}} & \multirow{2}{*}{\begin{tabular}{|l} 
High \\
animal \\
$(68)$
\end{tabular}} & \multirow{2}{*}{$\begin{array}{l}\text { Rising } \\
\text { science } \\
(25.5 \\
->12)\end{array}$} \\
\hline food (29) & N/A & $\begin{array}{l}\text { animal } \\
(54)\end{array}$ & N/A & & & $\begin{array}{l}\text { game } \\
(12.5 \mathrm{~s}->6)\end{array}$ & & & $\begin{array}{l}\text { sheep } \\
(16.5 \mathrm{~s} \\
->12)\end{array}$ & & & & \\
\hline water (27) & N/A & $\begin{array}{l}\text { water } \\
\text { (42) }\end{array}$ & $\mathrm{N} / \mathrm{A}$ & \multicolumn{2}{|c|}{ water (30) } & bat $(19->9)$ & \multicolumn{2}{|c|}{ water (41) } & $\begin{array}{l}\text { meat }(19 \\
->15.5 \mathrm{~s})\end{array}$ & $\begin{array}{l}\text { water; human } \\
(32)\end{array}$ & sky $(13->7)$ & $\begin{array}{l}\text { water } \\
(52)\end{array}$ & $\begin{array}{l}\text { light }(17 \\
->13.5 \mathrm{~s})\end{array}$ \\
\hline toy (25) & N/A & $\begin{array}{l}\text { earth } \\
\text { (33) }\end{array}$ & $\mathrm{N} / \mathrm{A}$ & \multicolumn{2}{|c|}{ toy (25) } & $\begin{array}{l}\text { camping } \\
(30->14)\end{array}$ & \multicolumn{2}{|c|}{ fish (40) } & $\begin{array}{l}\text { cheese } \\
(46.5 \mathrm{~s} \\
->19.5 \mathrm{~s})\end{array}$ & toy (28) & $\begin{array}{l}\text { chicken (42- } \\
>31)\end{array}$ & $\begin{array}{l}\text { human } \\
(47)\end{array}$ & $\begin{array}{l}\text { art }(42 \\
->24.5 s)\end{array}$ \\
\hline shoe (22) & N/A & $\begin{array}{l}\text { fish } \\
(32)\end{array}$ & $\mathrm{N} / \mathrm{A}$ & \multicolumn{2}{|c|}{ nature (24) } & $\begin{array}{l}\text { farm }(58 \\
->19.5 s)\end{array}$ & \multicolumn{2}{|c|}{ earth (38) } & $\begin{array}{l}\text { time }(24 \\
->19.5 \mathrm{~s})\end{array}$ & shoe (27) & $\begin{array}{l}\text { desert; house } \\
(34.5 \mathrm{~s} \\
->31 \mathrm{~s})\end{array}$ & \begin{tabular}{|l} 
earth \\
$(42)$
\end{tabular} & $\operatorname{dog}_{->28)}(34.5 \mathrm{~s}$ \\
\hline $\begin{array}{l}\text { tiger; sky } \\
(20)\end{array}$ & $N / A$ & $\begin{array}{l}\text { Wood } \\
(30)\end{array}$ & $\mathrm{N} / \mathrm{A}$ & \multicolumn{2}{|c|}{ tiger (23) } & $\begin{array}{l}\text { salad } \\
(39.5 \mathrm{~s} \\
->25.5 \mathrm{~s})\end{array}$ & \multicolumn{2}{|c|}{ bird (35) } & $\begin{array}{l}\text { compute } \\
\mathrm{r}(58 \\
->22.5 \mathrm{~s})\end{array}$ & meat; sky (25) & $\begin{array}{l}\text { gardening; } \\
\text { white ( } 49 \\
->35.5 \mathrm{~s})\end{array}$ & fish (40) & $\begin{array}{l}\text { fat }(58 \\
->31)\end{array}$ \\
\hline $\begin{array}{l}\text { time; wind; } \\
\text { red (19) }\end{array}$ & N/A & $\begin{array}{l}\text { bird } \\
(29)\end{array}$ & $\mathrm{N} / \mathrm{A}$ & \multicolumn{2}{|c|}{ game (22) } & $\operatorname{milk}_{->29)}(122$ & turkey & (33) & $\begin{array}{l}\text { day } \\
39.5 \mathrm{~s} \\
->25.5 \mathrm{~s}\end{array}$ & bat (24) & $\begin{array}{l}\text { bed }(34.5 \\
->35.5)\end{array}$ & $\begin{array}{l}\text { wood } \\
\text { (38) }\end{array}$ & $\begin{array}{l}\text { life }(34.5 s \\
->31)\end{array}$ \\
\hline $\begin{array}{l}\text { meal; pet; } \\
\text { game (18) }\end{array}$ & N/A & $\begin{array}{l}\text { sun } \\
(27)\end{array}$ & N/A & red ( & 21) & $\begin{array}{l}\text { day }(39.5 \\
->29)\end{array}$ & food $(3$ & & $\begin{array}{l}\text { grass } \\
30 \\
->25.5 \mathrm{~s}\end{array}$ & $\begin{array}{l}\text { tiger; kitchen } \\
\text { (23) }\end{array}$ & $\begin{array}{l}\text { light (97 } \\
->43)\end{array}$ & $\begin{array}{l}\text { turkey } \\
(37)\end{array}$ & $\begin{array}{l}\text { fire }(49 \\
->35.5 s)\end{array}$ \\
\hline \begin{tabular}{l|} 
soup; party \\
$(17)$
\end{tabular} & N/A & $\begin{array}{l}\text { food } \\
(26)\end{array}$ & $\mathrm{N} / \mathrm{A}$ & $\begin{array}{l}\text { time } \\
(20)\end{array}$ & bat & $\operatorname{ship}_{->29)}$ & wood (C & & $\begin{array}{l}\text { gold } \\
(75.5 \mathrm{~s} \\
->29)\end{array}$ & $\begin{array}{l}\text { insect; time; } \\
\text { soup (22) }\end{array}$ & $\begin{array}{l}\text { door; ocean; } \\
\text { shark (58 } \\
->43 \text { ) }\end{array}$ & food (35) & $\underset{->43)}{\operatorname{metal}(179}$ \\
\hline \begin{tabular}{l|} 
bird; plant; \\
blue; bread; \\
bat; garden \\
(16)
\end{tabular} & N/A & $\begin{array}{l}\text { fruit } \\
(23)\end{array}$ & $\mathrm{N} / \mathrm{A}$ & $\begin{array}{l}\text { mea } \\
(19)\end{array}$ & ; soup & $\begin{array}{l}\text { yellow } \\
(46.5 \mathrm{~s} \\
->34.5 \mathrm{~s})\end{array}$ & $\begin{array}{l}\text { milk; st } \\
(25)\end{array}$ & & $\begin{array}{l}\text { family } \\
(58 \\
->34.5)\end{array}$ & $\begin{array}{l}\text { plant; red; pet; } \\
\text { game (21) }\end{array}$ & $\begin{array}{l}\text { blue }(49 \\
->43)\end{array}$ & $\begin{array}{l}\text { insect; } \\
\text { bird (33) }\end{array}$ & $\begin{array}{l}\text { lake (68 } \\
->43)\end{array}$ \\
\hline $\begin{array}{l}\text { meat; grass; } \\
\text { sea; road; } \\
\text { kitchen (15) }\end{array}$ & N/A & $\begin{array}{l}\text { horse } \\
(22)\end{array}$ & N/A & $\begin{array}{l}\text { pet; } \\
\text { cam } \\
(18)\end{array}$ & $\begin{array}{l}\text { sky; } \\
\text { ping }\end{array}$ & $\begin{array}{l}\text { desert } \\
(39.5 \mathrm{~s} \\
->34.5 \mathrm{~s})\end{array}$ & $\begin{array}{l}\text { fruit; sh } \\
\text { horse ( }\end{array}$ & $\begin{array}{l}\text { ieep; } \\
\text { 21) }\end{array}$ & $\begin{array}{l}\text { sport } 5 \\
->34.5 \mathrm{~s}\end{array}$ & $\begin{array}{l}\text { bread; wind; } \\
\text { mind; painting; } \\
\text { party (20) }\end{array}$ & ${ }_{->53)}^{\text {drink }(97}$ & $\operatorname{sun}(31)$ & $\begin{array}{l}\text { war }(42 \\
->43)\end{array}$ \\
\hline Oxford Wordlis & ist: Yea & & & & & & & Oxfo & ord Word & ist: Year 4 & & & \\
\hline As start conce & & & As end $\mathrm{CO}$ & oncep & & & & As st & start cono & ept & As end concep & & \\
\hline High & Risi & & High & & Rising & & & High & & Vising & High & Rising & \\
\hline food (52) & $\begin{array}{l}\text { red } \\
->7\end{array}$ & & animal $(73$ & & fat $(31$. & $>21)$ & & hum & $\tan (53)$ & $\begin{array}{l}\text { oor (36 } \\
>22.5 s)\end{array}$ & animal (73) & war (44 & $>22.5 \mathrm{~s})$ \\
\hline $\begin{array}{l}\text { water; human } \\
\text { (48) }\end{array}$ & $\operatorname{plan}_{\rightarrow 7}$ & $\begin{array}{l}\mathrm{t}(13.5 \mathrm{~s} \\
5 \mathrm{~s})\end{array}$ & Water (63) & & music & $(43->29.5 s)$ & & food & (48) & $\operatorname{ear}(73.5 s->31)$ & water (67) & life (61. & $>37.5 \mathrm{~s})$ \\
\hline transport (39) & $\begin{array}{l}\text { sau } \\
24 \\
->13\end{array}$ & 5 sage & earth (61) & & wind (5 & $53->36)$ & & wate & r (46) & $\begin{array}{l}\text { ound; garden (61 } \\
\text { >33) }\end{array}$ & earth (62) & $\begin{array}{l}\text { clothin } \\
73.5 \mathrm{~s}-\end{array}$ & $\rightarrow 42)$ \\
\hline meat (35) & $\begin{array}{l}\text { sea } \\
->17\end{array}$ & $\begin{array}{l}(24.5 \mathrm{~s} \\
.5 \mathrm{~s})\end{array}$ & human (5) & & $\begin{array}{l}\text { snow }(1 \\
->44)\end{array}$ & $61.5 \mathrm{~s}$ & & $\begin{array}{l}\operatorname{trans} \\
(45)\end{array}$ & sport & $\begin{array}{l}\text { ompetition ( } 67.5 \mathrm{~s} \\
>37.5 \mathrm{~s})\end{array}$ & human (58) & $\begin{array}{l}\text { gas }(12 \\
->47.5\end{array}$ & $\begin{array}{l}22.5 \mathrm{~s} \\
\text { s) }\end{array}$ \\
\hline toy (34) & $\begin{array}{l}\text { fruit } \\
->20\end{array}$ & $72.5 \mathrm{~s}$ & fish (46) & & $\begin{array}{l}\text { compu } \\
\text { salt; } w\end{array}$ & $\begin{array}{l}\text { ter; disease; } \\
\operatorname{ar}(43->44)\end{array}$ & planet; & $\begin{array}{l}\text { enter } \\
\text { ent }\end{array}$ & $\begin{array}{l}\text { intainm } \\
\text { (43) }\end{array}$ & $\begin{array}{l}\text { nachine } \\
61->37.5 \mathrm{~s})\end{array}$ & sun; fish (44) & $\begin{array}{l}\text { govern } \\
(61->4\end{array}$ & $\begin{array}{l}\text { ment; heart } \\
7.5 \mathrm{~s})\end{array}$ \\
\hline sky (33) & $\begin{array}{l}\text { road } \\
->25\end{array}$ & $\begin{array}{l}(43 \\
5 \mathrm{~s})\end{array}$ & wood (44) & & cancer & ; rain (53->51 & & natur & ure (42) & $\begin{array}{l}\text { erfume } \\
67.5 \mathrm{~s}->42)\end{array}$ & bird (43) & $\underset{->54)}{\text { pain }(1}$ & $32.5 \mathrm{~s}$ \\
\hline plant; red (31) & $\operatorname{skin}_{->25}$ & $\begin{array}{l}(31 \\
5 \mathrm{~s})\end{array}$ & sun (43) & & tree $(5$ & 3->55) & & shoe & e(34) & $\begin{array}{l}\text { loud (55 } \\
>42)\end{array}$ & wood (41) & $\begin{array}{l}\text { brain; } 1 \\
\text { river (8 }\end{array}$ & $\begin{array}{l}\text { medicine; } \\
33->62)\end{array}$ \\
\hline shoe (30) & $\operatorname{lhu}_{->29}$ & $\begin{array}{l}1.5 \mathrm{~s}) \\
1.51\end{array}$ & bird (42) & & $\begin{array}{l}\text { heart ( } \\
->61)\end{array}$ & $72.5 \mathrm{~s}$ & & toy $c$ & (33) & $\begin{array}{l}\text { lue }(61 \\
>47.5)\end{array}$ & copper (39) & $\begin{array}{l}\text { blood; } \\
73.5 \mathrm{~s}-\end{array}$ & $\begin{array}{l}\text { flower } \\
->62)\end{array}$ \\
\hline kitchen (29) & $\underset{b 31}{\text { pizz }}$ & $\begin{array}{l}a(43 \\
.5 s)\end{array}$ & $\begin{array}{l}\text { oxygen; ir } \\
(39)\end{array}$ & & $\begin{array}{l}\text { butter } \\
->61)\end{array}$ & $61.5 \mathrm{~s}$ & & red ( & (32) & $\begin{array}{l}\text { leath; hunting (83 } \\
\text { 54) }\end{array}$ & species (38) & $\begin{array}{l}\text { baseb: } \\
\text { transp } \\
->71.5\end{array}$ & $\begin{array}{l}\text { all; grass; } \\
\text { ort (92.5s } \\
\text { s) }\end{array}$ \\
\hline $\begin{array}{l}\text { time; sausage; } \\
\text { soup (28) }\end{array}$ & $\begin{array}{l}\operatorname{ship}_{->31} \\
\end{array}$ & $\begin{array}{l}(31 \\
.5 s)\end{array}$ & $\begin{array}{l}\text { food; spe } \\
\text { (38) }\end{array}$ & & glass; & bread (53->6 & & $\begin{array}{l}\text { tech } \\
\text { sky }\end{array}$ & $\begin{array}{l}\text { inology: } \\
(30)\end{array}$ & $\begin{array}{l}\text { ay }(73.5 \\
>54)\end{array}$ & food (37) & $\begin{array}{l}\text { ocean } \\
->76.5\end{array}$ & $\begin{array}{l}(92.5 \mathrm{~s} \\
\mathrm{s})\end{array}$ \\
\hline
\end{tabular}

Based on earlier research it seems that knowledge adoption through reading can have somewhat lower levels than listening but still managing daily rate of about 1647-12967 words [19] corresponding with an average length of 20 words in sentence [22] to reading 80-648 sentences which can take with a suggested reading speed of 200 words per minute [20] about 8-65 minutes. Motivated by these estimates we concluded based on earlier research, we suggest that adoption of vocabulary by exploration in 
hyperlink network of vocabulary can be usefully carried out in a daily process that resembles reading 80-648 sentences.

Since each hyperlink in the Wikipedia typically has its own sentence (in article text surrounding hyperlink anchor) defining the relationship between start concept and end concept, and since the shortest path between a pair of concepts has on average 4,573 hyperlink steps in the Wikipedia [27], knowledge adoption of 80-648 sentences per day can be considered to correspond to traversing shortest paths of about 17-142 average pairs of concepts in hyperlink network of vocabulary. Based on previous recommendations of about 3-4 spaced exposures to enable fertile learning [11] [13] [12], it seems that traversing 17-142 shortest paths can be considered to correspond to (i.e. when dividing the number of shortest paths by 3 or 4 to enable 3-4 repetitions) an aim to learn connectivity relying on the shortest paths for about 4-47 pairs of concepts with every daily session of exploring hyperlink network of vocabulary. This result can be contrasted with and seems to resemble earlier estimates that a student can adopt daily about 4-9 new words [17] [18] [3].

Instead of considering the shortest paths of varying length we can make a simplifying assumption that language learning can be represented as a process of adoption of direct relationships between nouns belonging to a vocabulary and based on Table 1 for vocabulary A1\&A2\&B1\&B2\& $\mathrm{C} 1 \& \mathrm{C} 2$ this corresponds to adoption of 25153 unique Wikipedia hyperlinks connecting 2878 unique nouns in vocabulary. If we assume based on previously mentioned results [8] [9], that to reach the range of language ability levels A1-C2 requires about 1000-1200 guided hours of learning, then for learning each of 25153 direct unique relationships between 2878 unique concepts there is on average 143-172 seconds to be used. If we assume based on previously mentioned results a suggested reading speed of about 200 words per minute [20] [21] and an average sentence length of 20 words [22], during this given time range of 143-172 seconds it is possible to read about 477-572 words corresponding to 24-29 sentences. If this given time range is divided to for example three spaced learning sessions that offer exposure and retention then each of these three sessions has about 48-57 seconds corresponding to about 8,0-9,5 sentences devoted to learn one of 25153 unique relationships between 2878 unique concepts. Of course this kind of modelling about learning process is only a coarse simplification but we think that it can be useful to analyze learning also with this kind of simplifications to develop new methods to support learning.
We hope that the proposed framework can open new possibilities for developing innovative methods of computer-assisted learning relying on knowledge structures managed with scale-free small-world networks. We suggest that personalization of learning activities can benefit from exploring collaboratively built and gradually updated free knowledge resources of the Wikipedia online encyclopedia that inherently offers a diverse collection of hyperlinks defining conceptual relationships usable for varied pedagogic purposes. We think that the principle of cumulatively expanding hyperlink networks covering more and more linkage between concepts of gradually growing vocabulary can enable an efficient and intuitive way to explore and adopt new knowledge meaningfully as well as to develop new kind of educational games that can be extended to manage diverse content besides text like images, videos, and tasks with augmented reality and tracking kinetic activities.

\section{References}

[1] Wang, J., Zuo, X., \& He, Y. (2010). Graph-based network analysis of resting-state functional MRI. Frontiers in Systems Neuroscience, 4(16), 1-14.

[2] Ingawale, M., Dutta, A., Roy, R., \& Seetharaman, P. (2009). The small worlds of Wikipedia: implications for growth, quality and sustainability of collaborative knowledge networks. Proc. Americas Conference on Information Systems (AMCIS 2009).

[3] Nation, P., \& Waring, R. (1997). Vocabulary size, text coverage, and word lists. In Schmitt, N., \& McCarthy, M. (eds.), Vocabulary: description, acquisition, pedagogy. Cambridge University Press, New York, USA, 6-19.

[4] Nation, I. (2006). How large a vocabulary is needed for reading and listening? Canadian Modern Language Review, 63(1), 59-82.

[5] Laufer, B. (1989). What percentage of text-lexis is essential for comprehension? In Lauren, C., \& Nordman, M. (eds.), Special language: from humans thinking to thinking machines. Multilingual Matters, Clevedon, UK.

[6] Council of Europe (2001). Common European Framework of Reference for Languages: Learning, Teaching, Assessment. Council of Europe. Cambridge University Press, ISBN 0521803136. http://www.coe.int/t/dg4/linguistic/Source/ CECR_EN.pdf

[7] North, B. (1996/2000). The development of a common framework scale of language proficiency. 
PhD thesis, Thames Valley University, UK. Reprinted 2000, Peter Lang, New York, USA.

[8] European Commission (2012). Language competences for employability, mobility and growth. Commission staff working document SWD 2012/372 accompanying the COM 2012/669. http://eurlex.europa.eu/legal-content/EN/TXT/PDF/ ?uri=CELEX:52012SC0372\&qid=1397571317864\& from $=\mathrm{EN}$

[9] Cambridge English for Speakers of Other Languages (ESOL) / Cambridge English Language Assessment (2013). http://www.cambridgeesol.org/ about/standards/can-do.html redirected to http://www.cambridgeenglish.org/about-us/whatwedo/international-language-standards/ (as of 15 April 2014).

[10] Sanatullova-Allison, E. (2009). Less commonly taught languages: often overlooked but equally important. Language Association Journal, 60(2).

[11] Thalheimer, W. (2006). Spacing learning events over time: what the research says. Will Thalheimer, Work-Learning Research Inc., Somerville, Massachusetts, USA. March 2006.

http://willthalheimer.typepad.com/files/spacing_lear ning_over_time_2006.pdf

[12] Kandel, E. (2001). The molecular biology of memory storage: a dialog between genes and synapses. Nobel Lecture, 8 December 2000. Bioscience Reports, 21(5).

[13] Fields, R. (2005). Making memories stick. Scientific American, 292 (February 2005), 74-81.

[14] Gilkerson, J., \& Richards, J. (2009). The power of talk, 2nd edition. Impact of adult talk, conversational turns, and TV during the critical 0-4 years of child development. LENA Technical Report LTR-01-2. LENA Research Foundation.

http://www.lenababy.com/pdf/

The_Power_of_Talk.pdf

[15] Mehl, M., Vazire, S., Ramirez-Esparza, N., Slatcher, R., \& Pennebaker, J. (2007). Are women really more talkative than men? Science, $317,82$.

[16] Juster, F., Ono, H., \& Stafford, F. (2004). Changing times of American youth: 1981-2003. Institute for Social Research, University of Michigan, Ann Arbor, Michigan, USA

(November 2004).

http://www.ns.umich.edu/Releases/2004/Nov04/ teen_time_report.pdf
[17] Lehr, F., Osborn, J. \& Hiebert, E. (2004). Research-based practices in early reading series: a focus on vocabulary. Regional Educational Laboratory, Pacific Resources for Education and Learning. http://vineproject.ucsc.edu/resources/ A\%20Focus\%20on\%20Vocabulary\%20PREL.pdf

[18] Kuhn, M., \& Stahl, S. (1998). Teaching children to learn word meanings from context: a synthesis and some questions. Journal of Literacy Research, 30(1), 119-138.

[19] Anderson, R., Wilson, P., \& Fielding, L. (1988). Growth in reading and how children spend their time outside of school. Reading Research Quarterly, 23, 285-303.

[20] Lewandowski, L., Codding, R., Kleinmann, A., \& Tucker, K. (2003). Assessment of reading rate in postsecondary students. Journal of Psycho educational Assessment, 21, 134-144.

[21] Anderson, N. (1999). Improving reading speed. English Teaching Forum, 37(2).

[22] DuBay, W. (2004). The principles of readability. William H. DuBay, Impact Information, Costa Mesa, California, USA. 25 August 2004. http://www.impact-information.com/ impactinfo/readability02.pdf

[23] Najork, M., Zaragoza, H., \& Taylor, M. (2007). HITS on the Web: how does it compare? Proc. 30th Annual International ACM SIGIR Conference on Research and Development in Information Retrieval, 471-478.

[24] Kamps, J., \& Koolen, M. (2009). Is Wikipedia link structure different? Proc. Second ACM International Conference on Web Search and Data Mining (WSDM 2009), 232-241.

[25] Zlatic, V., Bozicevic, M., Stefancic, H., \& Domazet, M. (2006). Wikipedias as complex networks. Physical Review E, 74, 016115.

[26] Rodero-Merino, L., Fernández Anta, A., López, L., \& Cholvi, V. (2010). Performance of random walks in one-hop replication networks. Computer Networks 54(5), 781-796.

[27] Dolan, S. (2011). Six degrees of the Wikipedia, Stephen Dolan, Trinity College, Dublin, Irland. http://mu.netsoc.ie/wiki/

[28] Travers, J., \& Milgram, S. (1969). An experimental study of the small world problem. Sociometry 32(4), 425-443. 
[29] Backstrom, L., Boldi, P., Rosa, M., Ugander, J., \& Vigna, S. (2011). Four degrees of separation. Proc. 4th ACM International Conference on Web Science (WebSci).

[30] Chesney, T. (2006). An empirical examination of Wikipedia's credibility. First Monday, 11(11).

[31] Konieczny, P. (2012). Wikis and Wikipedia as a teaching tool: five years later. First Monday, 17(9).

[32] Lahti, L. (2012). Educational framework for adoption of vocabulary based on Wikipedia linkage and spaced learning. Proc. Global Learn 2012 online conference on 6 November 2012 (eds. Bastiaens, T., \& Marks, G.), 8-13, AACE. ISBN 1880094-99-1. http://www.editlib.org/p/42033/. zyypyspbvtabj tvtvttbzaölvvllb jtbt taj atavz ul åjtdt lyul öttvvl ul pwjxj.

[33] Capel, A. (2013). Completing the English Vocabulary Profile: C1 and C2 vocabulary. English Profile Journal, 3, e1.

[34] Brezina, V., \& Gablasova, D. (2013). Is there a core general vocabulary? Introducing the New General Service List. Applied Linguistics, first published online 26 August 2013. doi: 10.1093/applin/amt018.

[35] Leech, G., Rayson, P., \& Wilson, A. (2001). Word frequencies in written and spoken English: based on the British National Corpus. Longman, London, United Kingdom. ISBN 0582-32007-0. A companion web site: http://ucrel.lancs.ac.uk/ bncfreq/flists.html

[36] Lo Bianco, J., Scull, J., \& Ives, D. (2008). The words children write. Research summary of the Oxford Wordlist research study. Oxford University Press, South Melbourne, Australia.

[37] Bayetto, A. (2010). The words children write beyond the early years. Summary report of the Oxford Wordlist, stage 2 research study. Oxford University Press, South Melbourne, Australia.

[38] Bullmore, E., \& Sporns, O. (2009). Complex brain networks: graph theoretical analysis of structural and functional systems. Nature Reviews Neuroscience, 10(3), 186-198.

[39] Masucci, A., Kalampokis, A., Eguíluz, V., \& Hernández-García, E. (2011). Wikipedia information flow analysis reveals the scale-free architecture of the semantic space. Public Library of Science ONE (PLoS ONE), 6(2), e17333.
[40] Yen, J. (1971). Finding the k shortest loopless paths in a network. Management Science, 17(11), 712-716.

[41] Lahti, L., (to appear). Computer-assisted learning based on cumulative vocabularies, conceptual networks and Wikipedia linkage. Doctoral dissertation (submitted for evaluation in January 2014), Department of Computer Science and Engineering, Aalto University School of Science, Finland.

This journal article is an extended and corrected version of conference article "Lahti, L. (2013). Educational framework based on cumulative vocabularies, conceptual networks and Wikipedia linkage. Proc. London International Conference on Education (LICE 2013). 4-6 November 2013, London, UK (eds. Shoniregun, C., \& Akmayeva, G.), 470-478. ISBN 978-1-908320-16-2.”. 